ZOOLOGIA 28 (3): 312-320, June, 2011

doi: $10.1590 /$ S1984-46702011000300005

\title{
Sedimentary characteristics and their effects on hatching success and incubation duration of Caretta caretta (Testudines: Cheloniidae) in Espirito Santo, Brazil
}

\author{
Lauana Schneider Fadini'; Ary Gomes Silvaํ \& Paulo Dias Ferreira-Júnior ${ }^{1,2}$
}

\author{
${ }^{1}$ Centro Universitário Vila Velha, Rua Comissário José Dantas de Melo, 21, Boa Vista, 29102-770, Vila Velha, ES, Brazil. \\ ${ }^{2}$ Corresponding author. E-mail: pdfj@hotmail.com
}

\begin{abstract}
The beaches of Espírito Santo encompass the most important nesting sites of the loggerhead sea turtle, Caretta caretta (Linnaeus, 1758), in the South Atlantic Ocean. Previous research has shown that, unlike other nesting sites in Brazil, Espírito Santo harbors a large percentage of male individuals, which play an important role in maintaining the equilibrium of C. caretta populations in the South Atlantic. During the 2006/2007 reproductive season, four beaches presenting considerable geologic differences were monitored. The sedimentary features of the nesting sites (mineral composition, albedo, and grain size), nesting dates, and clutch sizes were correlated with hatching success and incubation duration. Results show that hatching success is mostly affected by clutch size - and to a lesser extent, by grain size and albedo. Incubation duration is more sensitive to the characteristics of the nesting site, being affected by nesting date, clutch size, mineral composition, and grain size. However, results from one nesting site cannot be generalized or extended to other sites, because sediment properties are functions of the geological framework of the area and the interaction among environmental variables is far too complex. Our results reveal the importance of protecting areas with large geologic diversity, since sedimentary characteristics may affect incubation duration and embryo survival. Our findings are important in the scope of management activities, as nest transfer may alter nest microenvironment, impacting incubation duration and hatching success.
\end{abstract}

KEY WORDS. Loggerhead sea turtle; ecology; nest; sediment; hatchling.

The loggerhead sea turtle, Caretta caretta (Linnaeus, 1758), is the main species nesting on the beaches of Espírito Santo, southeastern Brazil, clustering its nests at the mouth of the Doce River (BaptistotTe et al. 1999, 2003, Almeida \& Mendes 2007). Five stations of Projeto TAMAR/ICMBio, the Brazilian Sea Turtle Conservation Program, operate in the area, protecting and monitoring $240 \mathrm{~km}$ of nesting beaches (MARCOVALDI \& MarCOVALDI 1999, BАртіsтотте et al. 2003). The conservation efforts started in the past decades have reduced predation against nests and females. In recent years, these efforts have also increased the number of hatchings of C. caretta (see MARCovaldi \& CHALOUPKA 2007) and of Dermochelys coriacea (Vandelli, 1761). This is the only area where regular leatherback sea turtle nesting is known to occur in Brazil (Thomé et al. 2007, Santos \& Ferreira Júnior 2009). The transfer of nests under erosion and predation risks to adjacent areas or rookeries with sedimentary characteristics similar to the original nest site is one of the management strategies adopted by Projeto TAMAR/ICMBio (Marcovaldi \& Laurent 1996, Marcovaldi \& Marcovaldi 1999). The location where to transfer the nests is important because effects of incubation on sex ratio and hatching success have to be minimized (NARO-Maciel et al. 1999, Hawkes et al. 2007, SERAFini et al. 2008).
The sex in C. caretta is determined by the incubation temperature. The species' pivotal temperature in Brazil has been established as $29.2^{\circ} \mathrm{C}$ (Marcovaldi et al. 1997). There is a direct relationship between incubation temperature and embryonic development rate (Georges et al. 1994, 2004), and an inverse correlation between incubation temperature and incubation duration (Mrosovsky et al. 1984). The pivotal temperature and pivotal incubation duration have been defined similarly - the temperature and the duration of incubation that yields 50\% of hatchlings from each sex, respectively (MARCovaldi et al. 1997, Mrosovsky et al. 1999). Because sea turtles hatchlings and juveniles are not sexually dimorphic (WYNEKEN et al. 2007), the pivotal incubation duration constitutes a significant parameter used to estimate sex ratio (Godfrey et al. 1999, Godley et al. 2001a, Mrosovsky et al. 2002). The duration of pivotal incubation for C. caretta in Brazil is 59.3 days under fixed conditions in the lab as described by Marcovaldi et al. (1997). In field conditions, the duration of pivotal incubation is 59.9 days (Mrosovsky et al. 1999). In the latter studies, hatchlings from the beaches of Espírito Santo state were used.

When choosing the beach for nesting, a sea turtle has to consider several factors that can affect the hatching success and 
sex ratio of its offspring. The factors that lead to the nesting site choice and the consequences that the characteristics of the site have on reproductive success are not fully understood, and there is no single feature that can be generalized to all nesting sites (Miller et al. 2003). However, the following factors are known to be relevant: grain size (MorTIMER 1990, FerReIRA JúNIOR et al. 2008); beach vegetation cover (Spotila et al. 1987, SERAFINI et al. 2008); albedo (Hays et al. 2001); mineral composition of the sand (MiLTon et al. 1997, NARO-MACIEL et al. 1999); nest inundation (Foley et al. 2006); height above sea level, and distance from the sea (HORROCKS \& Scott 1991, Lopez-Castro et al. 2004). Sites with coarse sand have higher temperatures, shortening incubation duration; by contrast, the lower temperatures characteristic of fine sands increase incubation duration (FERREIRA JÚNIOR \& CASTRO 2003). Another factor affecting nest temperature is the sand's mineral composition- nests on quartz-rich sediments have temperatures up to $3.4^{\circ} \mathrm{C}$ higher than those located on biogenic sands (Milton et al. 1997). According to Hays et al. (2001), sand albedo, which is the capacity of the sand to reflect the solar radiation it receives, also affects nest temperature. Nests in darker sands absorb more solar radiation and therefore have increased temperatures when compared with nests that lie in lighter sand, which reflects more of the incoming radiation. Shadowing may also affect sand temperature and cause differences in sex ratio within the same nesting site (Morreale et al. 1982, Spotila et al. 1987). The present study evaluates the physical factors affecting the nest environment of C. caretta across different beaches on the coast of Espírito Santo, Brazil, by associating the sediment properties of the nesting sites with hatching success and incubation duration.

\section{MATERIAL AND METHODS}

The present study was carried out in four nesting sites of C. caretta, on the shores of Espírito Santo, southeastern Brazil, during the 2006/2007 reproductive season (Fig. 1). The nesting sites examined were at the Jacaraípe $\left(20^{\circ} 08^{\prime} \mathrm{S}, 40^{\circ} 11^{\prime} \mathrm{W}\right)$ and Mole $\left(20^{\circ} 15^{\prime} \mathrm{S}, 40^{\circ} 13^{\prime} \mathrm{W}\right)$ beaches in the town of Serra, and two areas to the north, the Pontal do Ipiranga $\left(19^{\circ} 12^{\prime} \mathrm{S}\right.$, $\left.39^{\circ} 42^{\prime} \mathrm{W}\right)$ and Povoação $\left(19^{\circ} 34^{\prime} \mathrm{S}, 39^{\circ} 46^{\prime} \mathrm{W}\right)$ beaches, in the municipality of Linhares. In geologic and geomorphologic terms, the beaches monitored in this study can be grouped into two distinct regions: the northern area, which is under the influence of the mouth of the Doce River, and the southern area, with abounding contribution of biogenic sediments (Muene 2006, Albino \& Suguio 2010). Biogenic sediments are in part formed by mineral grains and organism parts, like organic skeletons of mollusk shell, echinoderms and fragments of corals and coralline algae. Biogenic sediments present lower thermal conductivity and nests located in these sediments are colder than nest in quartz-rich sediments (Milton et al. 1997).

The northern side of the mouth of the Doce River, where the Povoação and Pontal do Ipiranga beaches are located, receives a significant load of siliciclastic sediments, especially

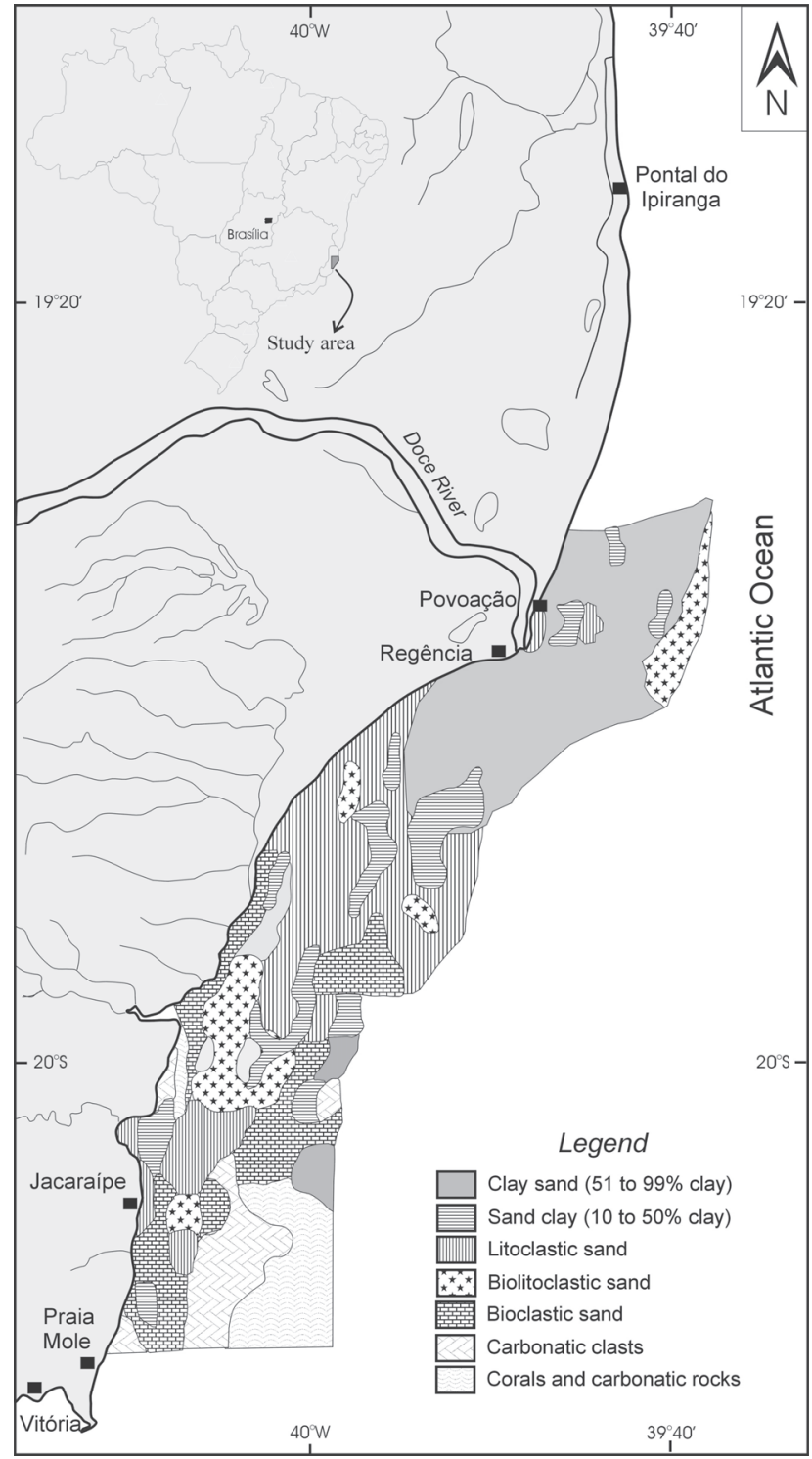

Figure 1. The map of facies of the sediments from the continental shelf between Vitoria and Povoação, near the Doce river mouth (after AlbINo \& SUGUIO 2010). It show that bioclasts sediments predominate in the southern region while sandy-muddy sediments are the majority at the northern region.

quartz, from the river and from the reworking of the of pleistocenic sand-beach ridges. The beaches are long and straight, often ending in steep borders, shaped by the erosion of the sand ridges. The grain size of sediments provides hints about wave speed in the environment, as judged from the composition of medium to coarse sand grains. Beaches are extensive in length, reaching tens of kilometers, and have no rocky outcrops on the shoreline; they are quite well-preserved, with 
a zone of scarce wild bushes called 'Restinga' (sandbank), composed of Ipomea pes-caprae Linnaeus and Blutaparon portulacoides St. Hill. The word 'Restinga' was originally used in reference to a geological formation of leached sandy soils poor in nutrients (SUGUio 1999). It has also been used in reference to a group of ecosystems ranging from flooded herbaceous land, hallophylous-psamophylous costal shores, open and close shrublands, and forests. The Restingas are under constant focus of conservationists, because they are believed to be extremely fragile environments that are very susceptible to disturbances (LACERDA et al. 1984, Pereira 2003).

The southern shore that comprises the Mole and Jacaraípe beaches is composed of biogenic sediments, which characterizes the mineralogy of the area. Marine bioclasts in Espírito Santo are mainly formed by coralline algae fragments. The Jacaraípe and Mole beaches receive siliclastic sediments (mainly quartz) from small rivers, but the contribution of the latter is fairly small when compared to the influence of the Doce River on the northern beaches. In geomorphologic terms, the southern beaches are shorter and limited by rocky outcrops and sandstone cliffs. Rocky outcrops extend into the sea and, along with reef formations, restraining female turtles from accessing parts of the beach. The "Restinga" vegetation zone has dense vegetation that shade part of the beaches and the berm.

Variations in sea hydrodynamics and in wave energy lead to changes in nest sites and in the sedimentary profile of beaches presenting fine and coarse sand layers. The sediments of the beach zone above high tide level are continually reworked by winds, which remove the finer fractions of sand, blowing these to the berm. When digging and closing their nests, turtles homogenize sediments that will cover the eggs by blending different sandy layers. In order to assess the influence of sediment size on the duration of incubation and on the hatching success of $C$. caretta, approximately $200 \mathrm{~g}$ samples were collected from all nests monitored. Sediments were collected at a depth of $10 \mathrm{~cm}$ in nests, in order to obtain a homogenous sample free of eolic influence. Data on the number of hatchlings (alive and dead), and unhatched eggs were obtained from the Projeto TAMAR/ICMBio. We used this data to calculate hatching success (the quotient of the number of live hatchlings to the total number of eggs in each nest), and incubation duration (the period that extends from nesting to the first emergence of hatchlings).

Albedo is the percentage of the incident solar radiation reflected by a surface. Darker sands tend to absorb more radiation, reaching higher temperatures when compared to lightcolored sands (Hays et al. 2001). Albedo readings were obtained on clear, cloudless days, under similar luminosity conditions. A photographic lightmeter (Luxímetro ITLD-260) was placed $25 \mathrm{~cm}$ above the ground to measure the reflected solar radiation at visible wavelengths. The standard used was the $18 \%$ grey card, and the protocol was that proposed by HaYs et al. (2001). Albedo was then calculated as the mean of five con- secutive readings of sand reflection, and compared with the $18 \%$ standard grey card. Since albedo of the grey card is known, it is possible to conduct comparisons with the albedo from the sand. This affords standardized measurements at the different beaches, at different moments. Albedo was examined for all monitored nests.

Calculation of the volumetric content of bioclasts was accomplished through the dissolution of calcium carbonate in hydrochloric acid. Samples were homogenized and $5 \mathrm{~g}$ from each nest was selected. They were weighed both before and after dissolution, and the amount of bioclast was calculated by the difference between the initial and final weights of the sample. The grain-size analysis was carried out by sieving and the subsequent application of Folk's (1974) scale. Because the quantity of clay was fairly small, usually less than $1 \%$ of the sample volume, the contents of silt and clay were not considered individually.

When data showed a normal distribution, differences among the beaches, including the biological (nesting date, number of alive and dead hatchlings, and clutch size) and physical (bioclast volume, albedo, and grain size) features were further investigated using the One-way ANOVA, followed by the Bonferroni post hoc test. For datasets that significantly strayed from the mean, differences were examined by the KruskallWallis nonparametric ANOVA on Ranks, followed by the Dunn post hoc test. Variables expressed as percentages (biogenic volume, albedo, grain size, hatching success), were transformed by the arcsine of its square root, in order to achieve data normalization (ZAR 2008). When necessary, data normality was tested by $\mathrm{K}^{2}$ and data homoscedasticity was tested by Bartlett $\chi^{2}$ (ZAR 2008). The predicting contribution of sedimentological factors and biological factors (nesting date and clutch size) in incubation duration and hatching success was estimated among all beaches and in each beach individually by stepwise backwards multiple regression, independently taking the number of days of incubation duration and the proportion of success in hatching, as dependent variables. The goodness of fit of regression residuals to the normal distribution was tested by $\mathrm{K}^{2}$. Normality tests were run on a programmed electronic sheet and all other statistical analysis were run in Systat, version 9.0.

\section{RESULTS}

Analyses of the properties of sediments from the nesting sites were carried out on 116 samples collected from October 2006 to March 2007, from nests in Mole $(\mathrm{n}=24)$, Jacaraípe $(\mathrm{n}=16)$, Povoação $(\mathrm{n}=43)$, and Pontal do Ipiranga $(\mathrm{n}=34)$ beaches. The nesting period (Kruskal-Wallis test $\mathrm{H}=6.243$, $\mathrm{p}=0.101)$ and the hatching period $(\mathrm{R}=4.82, \mathrm{p}=0.187) \mathrm{did}$ not show significant differences among the four beaches, indicating that incubation took place around the same time throughout the shores being monitored. On the northern coast, the Povoação and Pontal do Ipiranga beaches, associated with the mouth of Doce River, presented a larger number of nesting 
sites of $C$. caretta when compared with the southern Jacaraípe and Mole beaches.

Grain size differed among beaches (Tab. I). The Mole beach showed the coarsest sediments, with the coarse-sand fraction comprising, on average, over $80 \%$ of sediment. The finest sediments were from the Jacaraípe and Pontal do Ipiranga beaches, which were also the most similar in size. The amount of biogenic sediments varied among beaches, which we grouped in two pairs: 1) Mole and Jacaraípe beaches, with high contents of bioclast, constituting more than $35 \%$ of sediment volume and reaching as far up as $65 \%$ in Jacaraípe alone; and 2) the Pontal do Ipiranga and Povoação beaches, showing a bioclastic sediment volume proportion below $3 \%$, constituted mainly by siliciclastic minerals (mostly quartz) and heavy minerals (especially iron oxyhydroxides). Jacaraípe presented the highest reflection rate of solar radiation.

Clutch size and hatching success were the same throughout the beaches (Tab. I). Incubation duration differed considerably among the beaches and was longer in the southern beaches, Mole and Jacaraípe ( $n=32, \chi^{2}=62.8 \pm 4.29$ days), than in the Povoação and Pontal do Ipiranga beaches $(n=74$, $\chi^{2}=58.1 \pm 5.06$ days), located at the mouth of the Doce river.

When each beach was analyzed individually, the influence of environmental factors on hatching success varied across the areas, which makes it impossible to draw a common pattern across the nesting sites (Tab. II). Clutch size exerted a positive effect on hatching success in all beaches, except for Jacaraípe beach. Sediment grain size did not affect hatching success only at Pontal do Ipiranga. Albedo correlated positively with hatching success at the Jacaraípe and Pontal do Ipiranga beaches. When the four beaches were analyzed collectively, as if they represented a single nesting site, hatching success correlated to clutch size and grain size.
Table II. Stepwise backwards multiple linear regression for hatchings success of C. caretta in all beaches and in each individually.

\begin{tabular}{lrrr}
\hline \multicolumn{1}{c}{ Variable } & Coefficient & $\begin{array}{c}\text { Standard } \\
\text { coefficient }\end{array}$ & $p$ \\
\hline All beaches $\left(r^{2}=0.9498\right)$ & & & \\
Clutch size & 0.0072 & 0.7328 & $<0.0001$ \\
Granule & 0.6335 & 0.1820 & $<0.0001$ \\
Fine sand & 1.4672 & 0.1274 & $<0.0001$ \\
Mole beach $\left(r^{2}=0.9367\right)$ & & & \\
Clutch size & 0.0091 & 1.0500 & $<0.0010$ \\
Fine sand & 6.3100 & 0.2851 & 0.0114 \\
Very fine sand & -27.6543 & -0.3601 & 0.0071 \\
Jacaraípe beach $\left(r^{2}=0.9304\right)$ & & & \\
Albedo & 16.2312 & 0.5649 & 0.0118 \\
Fine sand & 1.1265 & 0.4237 & 0.0451 \\
Povoação beach $\left(r^{2}=0.9666\right)$ & & & \\
Clutch size & 0.0031 & 0.3046 & 0.0385 \\
Coarse sand & 0.6684 & 0.4282 & 0.0001 \\
Medium sand & 0.5741 & 0.2733 & 0.0045 \\
Pontal do Ipiranga beach $\left(r^{2}=0.9818\right)$ & & \\
Clutch size & 0.0037 & 0.3792 & 0.0004 \\
Albedo & 16.9770 & 0.6192 & $<0.0001$ \\
\hline & & & \\
\hline
\end{tabular}

The influence exerted on incubation duration by grain fractions varied across the beaches sampled. At Povoação beach, the nests located in coarse sand took less time to hatch. At Jacaraípe beach, incubation duration correlated positively with

Table I. Variation of biological and environmental factors across the nesting sites of C. caretta during the 2006/2007 reproductive season. Mean \pm standard deviation (sample size) * and means, followed by distinct letters at the same position, denote significance at the 0.05 level.

\begin{tabular}{|c|c|c|c|c|c|c|}
\hline Variables & Mole (24) & Jacaraípe (16) & Povoação (43) & Pontal do Ipiranga (33) & Parameter & $\mathrm{p}$ \\
\hline Incubation duration (days) & $62.26 \pm 4.60^{a}$ & $63.69 \pm 3.79 \mathrm{a}, \mathrm{c}$ & $58.52 \pm 3.63^{b, d}$ & $57.88 \pm 6.84^{b, d}$ & $F=7.81$ & $<0.010^{*}$ \\
\hline Hatching success (\%) & $66.41 \pm 30.19$ & $79.11 \pm 27.04$ & $82.5 \pm 18.91$ & $80.53 \pm 14.56$ & $\mathrm{H}=7.43$ & 0.059 \\
\hline Clutch size & $113.79 \pm 31.28$ & $115.36 \pm 19.75$ & $115.05 \pm 22.76$ & $111.44 \pm 27.39$ & $F=0.085$ & 0.932 \\
\hline Albedo (\%) & $18.5 \pm 0.95^{a}$ & $16.3 \pm 2.24 \mathrm{~b}, \mathrm{c}$ & $18.1 \pm 0.75^{\mathrm{a}, \mathrm{e}}$ & $17.8 \pm 1.31^{\mathrm{a}, \mathrm{e}}$ & $\mathrm{H}=9.85$ & $<0.006^{*}$ \\
\hline Biogenic sediment (\%) & $37.3 \pm 8.22 \mathrm{a}$ & $56.7 \pm 7.55^{b, c}$ & $0.77 \pm 0.57^{b, d}$ & $1.15 \pm 0.89 \mathrm{~b}, \mathrm{~d}$ & $\mathrm{H}=9.43$ & $<0.010^{*}$ \\
\hline \multicolumn{7}{|l|}{ Grain size } \\
\hline Gravel & $0.71 \pm 1.09$ a & $0.14 \pm 0.22^{b, c}$ & $2.19 \pm 2.21^{\mathrm{a}, \mathrm{d}, \mathrm{e}}$ & $0.12 \pm 0.20^{b, c, f}$ & $\mathrm{H}=54.41$ & $<0.010^{*}$ \\
\hline Very coarse sand & $10.44 \pm 8.45^{a}$ & $3.58 \pm 5.51 \mathrm{~b}, \mathrm{c}$ & $12.58 \pm 8.11^{\mathrm{a}, \mathrm{d}, \mathrm{e}}$ & $2.21 \pm 2.47^{b, c, f}$ & $H=47.86$ & $<0.010^{*}$ \\
\hline Coarse sand & $83.93 \pm 8.32 \mathrm{a}$ & $21.40 \pm 21.32^{b, c}$ & $47.03 \pm 14.93^{b, d, e}$ & $27.77 \pm 14.84^{b, c, f}$ & $H=117.20$ & $<0.010^{*}$ \\
\hline Medium sand & $4.72 \pm 3.55^{a}$ & $58.66 \pm 21.70^{b, c}$ & $28.96 \pm 13.61 \mathrm{~b}, \mathrm{~d}, \mathrm{e}$ & $51.39 \pm 9.44^{b, c, f}$ & $\mathrm{H}=75.12$ & $<0.010^{*}$ \\
\hline Fine sand & $0.18 \pm 0.50^{\mathrm{a}}$ & $15.12 \pm 12.12^{b, c}$ & $8.05 \pm 9.51^{b, c}$ & $15.73 \pm 9.50^{b}$ & $H=58.46$ & $<0.010^{*}$ \\
\hline Very fine sand & $0.02 \pm 0.02^{a}$ & $1.09 \pm 1.43^{b, c}$ & $1.18 \pm 2.32^{b, c, e}$ & $2.77 \pm 1.88^{b, c, f}$ & $\mathrm{H}=57.87$ & $<0.010^{*}$ \\
\hline
\end{tabular}


the grain fractions very coarse sand and medium sand, which suggests that the nests made in coarser sands take longer to hatch (Tab. III). In Mole and Povoação beaches clutch size presented a negative correlation with incubation duration, and nests with more eggs had shorter incubation duration.

When the beaches were examined collectively, incubation duration was affected by the nesting date, albedo, mineral composition and grain size (Tab. III). Clutches laid in the beginning of the reproductive season (October and November) had a longer incubation duration $\left(n=45, \chi^{2}=62.1 \pm 4.86\right.$ days $)$ than clutches laid toward the end of it it (December and January; $\mathrm{n}=61, \chi^{2}=57.6 \pm 4.78$ days). The amount of biogenic sediments also showed a positive correlation with incubation duration at the Mole beach, and a negative correlation at the Jacaraípe beach (with high volumes of bioclast).

\section{DISCUSSION}

Our results on the influence of most sediment characteristics and nesting date on incubation duration and hatching success differed depending on whether beaches were analyzed individually or collectively. Clutch size and grain size, however, were found to be affected by sediment characteristics in both types of analyses. Nests containing greater number of eggs presented higher hatching success, which may reflect the differences in gas volume among eggs, and gas exchange between the egg chamber and the surrounding medium (ACKERMAN 1980, ACKerman et al. 1985). Considering sediment size, although some correlations between grain fractions and the hatching success were highly significant, the volumetric contribution of these fractions to sediment size is very small, which makes it difficult to predict how they could lead to changes in nest environment and affect embryo survival. It was only at Povoação beach that the grain fractions coarse sand (47\%) and medium sand (28\%) are volumetrically representative and nests located in coarser sediments presented a higher hatching success. Sediment size plays a direct role on hydraulic conductivity, total porosity, air-filled pore space, salinity (Foley et al. 2006) and heat transfer (SouzA \& VogT 1994) with consequences to embryo survival. Apart from this, coarser sediments tend to be drier (MORTIMER 1990) and to present higher temperatures, which may reach lethal levels, reducing hatchling survival (GodLey et al. 2001b, HAwKEs et al. 2007). The coarser sediment in the surroundings of the mouth of the Doce River indicates a more dynamic environment. In this environment, tidal variation may affect the microenvironment of the nests, leading to nest flooding, which negatively impacts hatching success (Öz et al. 2004, Margaritoulis 2005, Foley et al. 2006).

The influence of the nesting site on hatching success greatly varies among the various species of sea turtle and the sites themselves (Miller et al. 2003). For instance, no differences are found in the hatching success of Eretmochelys imbricata (Linnaeus, 1766), a species that lays eggs in open beaches as
Table III. Stepwise backwards multiple linear regression for incubation duration of $C$. caretta in all beaches and in each beach individually.

\begin{tabular}{|c|c|c|c|}
\hline Variable & Coefficient & $\begin{array}{c}\text { Standard } \\
\text { Coefficient }\end{array}$ & $\mathrm{p}$ \\
\hline \multicolumn{4}{|c|}{ All beaches $\left(r^{2}=0.9933\right)$} \\
\hline Nesting date & -0.0741 & -0.1947 & 0.0005 \\
\hline Albedo & 1355.2900 & 0.9568 & $<0.0001$ \\
\hline Biogenic sediments & -8.4933 & -0.1885 & $<0.0001$ \\
\hline Very coarse sand & 10.1355 & 0.0488 & 0.0500 \\
\hline Coarse sand & 14.0154 & 0.1816 & 0.0277 \\
\hline Medium sand & 12.6632 & 0.1413 & 0.0068 \\
\hline Fine sand & 16.6645 & 0.0923 & 0.0191 \\
\hline \multicolumn{4}{|c|}{ Mole beach $\left(r^{2}=0.9988\right)$} \\
\hline Nesting date & -0.2051 & -0.5103 & $<0.0001$ \\
\hline Clutch size & -0.1319 & -0.2490 & 0.0001 \\
\hline Albedo & 3329.6600 & 2.2944 & $<0.0001$ \\
\hline Biogenic sediments & -54.3680 & -0.8007 & 0.0012 \\
\hline Very coarse sand & 51.6410 & 0.2664 & 0.0014 \\
\hline Fine sand & -96.8030 & -0.0718 & 0.0015 \\
\hline Very fine sand & 23.2090 & 0.0496 & 0.0100 \\
\hline \multicolumn{4}{|c|}{ Jacaraípe beach $\left(r^{2}=0.9988\right)$} \\
\hline Albedo & -1160.5000 & -0.7338 & 0.0040 \\
\hline Biogenic sediments & 74.8447 & 0.8457 & $<0.0001$ \\
\hline Granule & -120.9120 & -0.0632 & $<0.0001$ \\
\hline Very coarse sand & 78.9139 & 0.2347 & $<0.0001$ \\
\hline Medium sand & 53.0503 & 0.7758 & 0.0001 \\
\hline \multicolumn{4}{|c|}{ Povoação beach $\left(r^{2}=0.9978\right)$} \\
\hline Nesting date & -0.0906 & -0.2539 & 0.0009 \\
\hline Clutch size & -0.0740 & -0.1467 & 0.0008 \\
\hline Albedo & 938.0900 & 0.6790 & 0.0005 \\
\hline Biogenic sediments & 36.2720 & 0.9276 & $<0.0001$ \\
\hline Coarse sand & -16.4720 & -0.2168 & $<0.0001$ \\
\hline \multicolumn{4}{|c|}{$\begin{array}{l}\text { Pontal do Ipiranga beach } \\
\left(r^{2}=0.9963\right)\end{array}$} \\
\hline Nesting date & -0.2530 & 0.6629 & $<0.0001$ \\
\hline Biogenic sediments & 64.8720 & 1.6508 & $<0.0001$ \\
\hline
\end{tabular}

well as in the vegetation fringe. This, constancy is attributed to the greater stability and homogeneity of the sediments in the Guadeloupe beaches, French West Indies (Kamel \& Mrosovsky 2005). In Barbados, by contrast, E. imbricata shows a preference for beach zones, wherein hatching success is the highest in nests closest to mean elevation in the berm (HоRrocks \& Scotт 1991). 
In Bahia, Brazil, beach vegetation cover negatively influences the hatching success of E. imbricata (SERAFInI et al. 2008). The hatching success of Lepidochelys olivacea (Eschscholtz, 1829) in Baja California is affected by both distance from the sea and humidity in the nest (LOPEZ-CASTRO et al. 2004). For C. caretta in Patara beach, Turkey, hatching success is lower in the open beach than inland, with erosion and nest flooding being the main factors responsible for this difference (Öz et al. 2004). In Laganas Bay, Greece, hatching success varies among six beaches that are close to one another and all within $5.5 \mathrm{~km}$ of the coast. This variation has been attributed to differences in the physiographic features of the sites such as grain size, plant cover, and the presence of rocky outcrops between beaches (MARGaritoulis 2005). The beaches of Espírito Santo monitored in this study are more than $125 \mathrm{~km}$ apart and show remarkable geologic differences, and the discrepancies in sediment properties among the beaches of Espírito Santo affect the survival of embryos. In the present study, nests that could be eroded or flooded by the tide and that have been transferred as part of the methodology developed by Projeto TAMAR/ICMBio (Marcovaldi \& Marcovaldi 1999) were excluded. When comparing these results with those from other studies, it should be noted that only nests that had completed incubation and remained in situ have been used in the analyses, and the important role of the variation with relation to the dynamism of the beach (especially, the capacity of tides to flood or erode nests) has not been evaluated.

Incubation duration varied widely among the beaches and was greatly influenced by the properties of the sediments. However, it is not possible to draw a pattern that can be generalized. For instance, at Mole beach, the nesting date, clutch size, albedo, mineralogical composition and grain size affected incubation duration, whereas at Pontal do Ipiranga beach, only nesting date and mineralogical composition affected it. This fact shows the importance of extensively protecting nesting sites or even those areas that, in spite of being geographically small or close by, present great geologic diversity to the point of affecting the thermal environment of nests, with drastic consequences for both incubation duration (MARGARITOULIS 2005), sex ratio (HorRocks \& SCOTT 1991) and hatching success (Foley et al. 2006).

When the beaches were analyzed collectively, nesting date, albedo, grain size and mineral composition (volume of biogenic sediments) were observed to have influence on incubation duration. Nesting date has been selected as one of the main factors influencing nest temperature and embryonic development rate, having a direct effect on incubation duration (PIKE et al. 2006, Hawkes et al. 2007). Thus, incubation duration is longer in the beginning of the reproductive season of sea turtles, because the mean daily temperature is lower. In the course of the subsequent months, days become longer and warmer, and the nest temperatures tend to increase, shortening the incubation duration (Hewavisenthi \& Parmenter 2002, BAptistotTe et al. 2003). This correlation is common across the areas of reproduction of C. caretta (MROSOVSKy \& PROVANCHA 1989, NARO-MACIEL et al. 1999, Öz et al. 2004). The negative correlation between clutch size and incubation duration at Mole and Povoação beaches is attributed to metabolic heat: larger clutches lead to higher temperatures and shortened incubation duration (Maxwell et. al. 1988, KasKa et al. 1998, Godley et al. 2001b, Öz et al. 2004).

Albedo was the sedimentary variable that had the greatest influence on incubation, when beaches were analyzed together and individually. Of the four beaches analyzed, only Pontal do Ipiranga was not influenced by albedo. In general, in the nests situated in sediments with lower albedo (Povoação and Mole beaches), incubation duration was shorter, as indicated by other studies (NARO-MACIEL et al. 1999, HAYs et al. 2001). At Jacaraípe beach this trend was reversed, and the nests located in sediments with lower albedo presented longer incubation duration. This inversion is explained by the mineral composition of the sediments, which presented the highest levels of biogenic sediments at Jacaraípe beach. Fragments of coralline algae, abundant in this beach, are lighter in color than quartz minerals, which increase albedo. Nevertheless, biogenic sediments presented lower conductivity, leading to a lower incubation temperature (MilTon et al. 1997) and increased incubation duration. More specifically, mineral composition was more important and surpassed the influence of albedo on incubation duration at Jacaraípe beach. At Mole beach, which presented intermediate levels of bioclasts, the increase in biogenic sediment levels increased incubation duration.

The influence of grain size on incubation duration varied across beaches. At Povoação beach the increase in coarse sand fraction ( $\mathrm{x}=47 \pm 14.9 \%$ of the total volume) lead to a decrease in incubation duration, indicating that nests located in these sediments, predominantly quartz sediments, hatch sooner than nests located in fine sandy sediments (SouzA \& Vogt 1994, Naro-Maciel et al. 1999). At Mole and Jacaraípe beaches, the very coarse sand fraction $(\mathrm{x}=10.4 \pm 8.45 \%$ and $\mathrm{x}$ $=3.5 \pm 5.51 \%$ of total volume, respectively) correlated positively with incubation duration. In these beaches, the levels of biogenic sediments are high and the variation in grain size is not homogeneous across the different mineral components. The quartz grains are smaller and better selected than fragments of mollusk shell, corals and coralline algae. Therefore, the increase in grain size leads to a shift in mineral composition, favoring biogenic sediments that tend to decrease incubation duration due to the differences in heat absorption and transmission at depths (Milton et al. 1997).

The results of this research show the importance of protecting areas with great geologic diversity, wherein the features of the environment can affect the microenvironment of nests, with consequences on incubation duration and hatching success. The manner in which sediment properties vary depends largely on the geologic setting of the region and can hardly be generalized (Foley et al. 2006). Margaritoulis (2005) points to 
significant differences in the incubation duration in small beaches located near each other, attributing the differences to the quality of the sediment. The areas considered in this study, the Povoação and Pontal do Ipiranga beaches associated with the mouth of Doce River are very long, and their geologic features affect the hatching success and incubation duration. The southern beaches, which are associated with the biogenic sediments, are shorter, and show greater sediment variation due to the estuaries, cliffs, or old sand ridges that provide quartz sediments and alter the mineral composition of the beaches, with great consequences that affect incubation duration and hatching success.

The sex ratio of $C$. caretta is generally female-biased (Mrosovsky \& Provancha 1992, Hanson et al. 1998, Godley et al. 2001b). At the Beaches of Bahia, Brazil the sex ratio is strongly biased towards females -, but at the beaches of Espírito Santo associated with the mouth of Doce River, the sex ratio is not similarly biased (Marcovaldi et al. 1997, Mrosovsky et al. 1999, Naro-Maciel et al. 1999, Baptistotte et al. 1999). Beside Heron Island, Australia (Limpus et al. 1983) and Bald Head Island, NC, USA (HAwkes et al. 2007) the Espírito Santo coastline is one of the few sites in the world where sex ratios are not highly female biased (BAPTISTOTTE et al. 1999). Incubation duration is longer at the Mole and Jacaraípe beaches than at the beaches associated with the mouth of the Doce River. Considering the pivotal incubation duration of 59.9 days (Mrosovsky et al. 1999) and that the data were collected in one same reproductive season and under similar climatic conditions, the difference in incubation duration suggests a higher proportion of male hatchlings being born in the south beaches, when compared to the beaches to the north of the Doce River. Although constituting a smaller nesting total, hatchlings from the southern Espírito Santo beaches may be important to maintain the populations of $C$. caretta, evidencing the need to protect these nesting sites. Therefore, protection should not be restricted to the major nesting sites, but should also encompass the beaches with sparse distribution of nests, which present peculiar features that may affect the sex ratio and hatching success. The physiographic differences in nesting areas may add to hatchling variability and phenotypical characteristics like size and growth rates at juvenile stages may be useful considering hatchling and adult survival (McGehee 1990, Foley et al. 2006). In a scenario where most rookeries of $C$. caretta produce a female-biased sex ratio, it is important to protect the areas where a higher male production is observed (HAwKes et al. 2007). These areas may play an important role in the viability of $C$. caretta populations in the southern Atlantic Ocean.

\section{ACKNOWLEDGMENTS}

The authors would like to thank the Projeto TAMAR/ ICMBio for allowing access to its facilities and database. Special thanks to C. Baptistotte, E. Torezani, A. Pádua, A. Schneider, and to the Projeto TAMAR/ICMBio staff and university students, who helped in collecting data. This research had support by the Centro Universitário Vila Velha through project 06/2007. All procedures and handling of turtle hatchlings were authorized by the Projeto TAMAR/ICMBio.

\section{LITERATURE CITED}

Ackerman, R.A. 1980. Physiological and ecological aspects of gas exchange by sea turtle eggs. American Zoologist 1980 (5): 575-583.

Ackerman, R.A.; R.C. Seagrave; R. Dmi'el \& A. Ar. 1985. Water and heat exchange between parchment-shelled reptile eggs and their surroundings. Copeia 1985 (3): 703-711.

Albino, J. \& K. Suguio. 2010. Sedimentation processes and beach morphodynamics active at the Doce River mouth, Espírito Santo State, Brazil. Anais da Academia Brasileira de Ciências 82 (4): 1031-1044.

Almeida, A.P. \& S.L. Mendes. 2007. An analysis of the role of local fishermen in the conservation of the loggerhead turtle (Caretta caretta) in Pontal do Ipiranga, Linhares, ES, Brazil. Biological Conservation 134 (1): 106-112.

Baptistotte, C.; J.T. Scalfone \& N. Mrosovsky. 1999. Maleproducing thermal ecology of a southern turtle nesting beach in Brazil: implications for conservation. Animal Conservation 2 (1): 9-13.

Baptistotte, C.; J.C.A. Thomé \& K. BJordnal. 2003. Reproductive and biology conservation status of the loggerhead sea turtle (Carreta caretta) in Espírito Santo State. Brail. Chelonian Conservation and Biology 4 (3): 523-529.

Ferreira Júnior, P.D. \& P.T.A. Castro. 2003. Geological control of Podocnemis expansa and Podocnemis unifilis nesting areas in Rio Javaés, Bananal Island, Brazil. Acta Amazonica 33 (3): 445-468.

Ferreira Júnior, P.D.; M.F. Rosa; M. Lorenzo; M.F. Monteiro \& R.R. Azevedo. 2008. Influência das características geológicas do local de desova na duração da incubação e no sucesso da eclosão dos ovos de Caretta caretta na praia da Guanabara, Anchieta, Espírito Santo. Iheringia, Série Zoologia 98 (4): 447-453.

Foley, A.M.; S.A. Peck \& G.R. Harman. 2006. Effects of sand characteristics and inundation on the hatching success of Loggerhead Sea Turtle (Caretta caretta) clutches on low-relief mangrove islands in southwest Florida. Chelonian Conservation and Biology 5 (1): 32-41.

FolK, R.L. 1974. Petrology of sedimentary rocks. Austin, Texas, Hemphill Publishing Company, 181p.

Georges, A.; C. Limpus \& R. STOUTJESDIJK. 1994. Hatchling sex in the marine turtle Caretta caretta is determined by proportion of development at a temperature, not daily duration of exposure. Journal of Experimental Zoology 270 (3): 432-444.

Georges, A.; S. Doody; K. Beggs \& J. Young. 2004. Thermal models of TSD under laboratory and field conditions, p. 79-89. In: N. 
VALENZuela \& V.A. LANCE (Eds). Temperature-dependent sex determination in vertebrates. Washington, Smithsonian Books.

Godfrey, M.H.; A.F. D'Amato; M.A. Marcovaldi \& N. Mrosovsky. 1999. Pivotal temperature and predicted sex ratios for hatchling hawksbill turtles from Brazil. Canadian Journal of Zoology 77 (9): 1465-1473.

Godley, B.J.; A.C. Broderick \& N. Mrosovsky. 2001a. Estimating hatchling sex ratios of loggerhead turtles in Cyprus from incubation durations. Marine Ecology Progress Series 210: 195-201.

Godley, B.J.; A.C. Broderick; J.R. Downie; F. Glen; J.D. Houghton; I. KirKWood; S. ReEce \& G.C. Hays. 2001b. Thermal conditions in nests of loggerhead turtles: further evidence suggesting female skewed sex ratios of hatchling production in the Mediterranean. Journal of Experimental Marine Biology Ecology 263 (1): 45-63.

Hanson, J.; T. Wibbels \& R.E. Martin. 1998. Predicted female bias sex ratios of hatchling loggerhead sea turtles from a Florida nesting beach. Canadian Journal of Zoology 76 (10): 18501861.

Hays, G.C.; J.S. Ashworth; M.J. Barnsley; A.C. Broderick; D.R. Emery; B.J. Godley; A. Henwood \& E.L. Jones. 2001. The importance of sand albedo for the thermal conditions on sea turtle nesting beaches. Oikos 93 (1): 87-95.

Hawkes, L.A.; A.C. Broderick; M.H. Godfrey \& B.J. Godley. 2007. Investigating the potential impacts of climate change on a marine turtle population. Global Change Biology 13 (5): 923-932.

Hewavisenthi, S. \& C.J. Parmenter. 2002 Incubation environment and nest success of the Flatback Turtle (Natator depressus) from a natural nesting beach. Copeia 2002 (2): 302-312.

HorRoCKs, J.A. \& N.M. ScotT. 1991. Nest site selection and nest success in the hawksbill turtle, Eretmochelys imbricata, in Barbados, West Indies. Marine Ecology Progress Series 69: 1-8.

Kamel, S.J. \& N. Mrosovsky. 2005. Repeatability of nesting preferences in the hawksbill sea turtle, Eretmochelys imbricata, and their fitness consequences. Animal Behaviour 70 (4): 819-828.

KasKa, Y.; R. Downie; R. Tippett \& R.W. Furness. 1998. Natural temperature regimes for loggerhead and green turtle nests in the eastern Mediterranean. Canadian Journal of Zoology 76 (4): 723-729.

Lacerda, L.D.; D.S.D. Araújo; R. Cerqueira \& B. Turcq. 1984. Restingas: origem, estrutura, processos. Niterói, Centro Editorial da Universidade Federeal Fluminense, 475p.

Limpus, C.J.; P. Reed \& J.D. Miller. 1983. The inûuence of choice of nesting beach on sex ratio, p. 397-402. In: J.J. BAKER; R.M. Carter: P.W. Sammarco \& K.P. Stark (Eds). Proceedings Inaugural Great Barrier Reef Conference. North Queensland, James Cook University Press.

López-Castro, M.C.; R. Carmona \& W.J. Nichols. 2004. Nesting characteristics of the olive ridley turtle (Lepidochelys olivacea) in Cabo Pulmo, southern Baja California. Marine Biology 145 (4): 811-820.

Marcovaldi, M.A. \& M. Chaloupka. 2007. Conservation status of the loggerhead sea turtle in Brazil: an encouraging outlook. Endangered Species Research 3: 133-143.

Marcovaldi, M.A. \& A. Laurent. 1996. A six-season study of marine turtle nesting at Praia do Forte, Bahia, Brazil, with implications for conservation and management. Chelonian Conservation and Biology 2 (1): 55-59.

Marcovaldi, M.A. \& G.G. Marcovaldi. 1999. Marine turtles of Brazil: the history and structure of Projeto TAMAR-IBAMA. Biological Conservation 91 (1): 35-41.

Marcovaldi, M.A.; M.H. Godfrey \& N. Mrosovsky. 1997. Estimating sex ratios of loggerhead turtles in Brazil from pivotal incubation durations. Canadian Journal of Zoology 75 (5): 755-770.

Margaritoulis, D. 2005. Nesting activity and reproductive output of loggerhead sea turtles, Caretta caretta, over 19 seasons (1984-2002) at Laganas Bay, Zakynthos, Greece: The largest rookery in the Mediterranean. Chelonian Consservation and Biology 4 (4): 916-929.

Maxwell, J.A.; M.A. Motara \& G.H. Frank. 1988. A microenvironmental study of the effect of temperature on the sex ratios of the loggerhead sea turtle, Caretta caretta, from Tongaland, Natal. South African Journal of Zoology 23 (4): 342-50.

McGenee, M.A. 1990. Effects of moisture on eggs and hatchlings of loggerhead sea turtle (Caretta caretta). Herpetologica 46 (3): 251-258.

Miller, J.D.; C.L. Limpus \& M.H. Godfrey. 2003. Nest site selection. oviposition. eggs. development. hatching. and emegence of loggerhead sea turtles, p. 125-143. In: A.B. Bolten \& B.E. Witherington (Eds). Loggerhead Sea Turtles. Washington, D.C., Smithsonian Books.

Milton, L.; A.A. Schulman \& P.L. Lutz. 1997. The effect of beach nourishment with aragonite versus silicate sand on beach temperature and loggerhead sea turtle nesting success. Journal of Costal Research 13 (3): 904-915.

Morreale, S.J.; G.J. Ruiz; J.R. Spotila \& E.A. Standora. 1982. Temperature-dependent sex determination: current practices threaten conservation of sea turtles. Science 216 (4551): 1245-1247.

Mortimer, J.A. 1990. The influence of beach sand characteristics on the nesting behavior and clutch survival of green turtles (Chelonia mydas). Copeia 1990 (3): 802-817.

Mrosovsky, N. \& J. Provancha. 1989. Sex ratio of loggerhead sea turtles hatching on a Florida beach. Canadian Journal of Zoology 67 (10): 2533-2539.

Mrosovsky, N. \& J. Provancha. 1992. Sex ratio of hatchling loggerhead sea turtles: data and estimates from a 5-year study. Canadian Journal of Zoology 70 (3): 530-538.

Mrosovsky, N.; P.H. Dutton \& C.P. Whitmore. 1984. Sex ratios of two species of sea turtle nesting in Suriname. Canadian Journal of Zoology 62 (11): 2227-2239. 
Mrosovsky, N.; C. Baptistotte \& M.H. Godfrey. 1999. Validation of incubation duration as an index of the ratio of hatchling sea turtles. Canadian Journal of Zoology 77 (5): 831-835.

Mrosovsky, N.; S. Kamel; A.F. Rees \& D. Margaritoulis. 2002. Pivotal temperature for loggerhead turtles (Caretta caretta) from Kyparissia Bay. Greece. Canadian Journal of Zoology 80 (12): 2118-2124.

Muene, D. 2006. Erosão e progradação do litoral do Brasil. Brasília, Minstério de Meio Ambiente, 475p.

Naro-Maciel, E.; N. Mrosovsky \& M.M.Â. Marcovaldi. 1999. Thermal profiles of sea turtle hatcheries and nesting areas at Praia do Forte. Brazil. Chelonian Conservation and Biology 3 (3): 407-413.

Öz, M.; A. Erdogan; Y. Kaska; S. Dusen, A. Aslan; H. Sert; M. Yavuz $\&$ M.R. Tunc. 2004. Nest temperatures and sex-ratio estimates of loggerhead turtles at Patara beach on the southwestern coast of Turkey. Canadian Journal of Zoology 82 (1): 94101.

Pereira, O.J. 2003. Restinga: origem, estrutura e diversidade, p. 177-179. In: M.A.G. JaRdim; M.N.C. Bastos \& J.U.M. Santos (Eds). Desafios da botânica no novo milênio: inventário, sistematização e conservação da diversidade vegetal. Belém, Embrapa, Museu Paraense Emílio Goeldi.

Pike, D.A.; R.L. Antworth \& J.C. Stiner. 2006. Earlier nesting contributes to shorter nesting seasons for the Loggerhead Seaturtle, Caretta Caretta. Journal of Herpetology 40 (1): 91-94.

Santos, C.H. \& P.D. Ferreira Júnior. 2009. Influência do local da desova na incubação de Dermochelys coriacea Vandelli, 1761
(Testudines: Dermochelyidae) na Reserva Biológica de Comboios, norte do estado do Espírito Santo, Brasil. Biota Neotropica 9 (3): 1-6.

Serafini,T.Z.; G.G. Lopez \& P.L.B. Rocha. 2008. Nest site selection and hatching success of hawksbill and loggerhead sea turtles (Testudines, Cheloniidae) at Arembepe Beach, northeastern Brazil. Phyllomedusa 8 (1): 3-17.

Souza, R.R. \& R.C. Vogt. 1994. Incubation temperature influences sex and hatchling size in the neotropical turtle Podocnemis unifilis. Journal of Herpetology 28 (4): 453-464.

Spotila, J.R.; E.A. Standora; S.J. Morreale \& G. Ruiz. 1987.Temperatura dependent sex determination in the turtle (Chelonia mydas): effects on the ratio on a natural nesting beach. Herpetologica 43 (1): 74-81.

Suguio, K. 1999. Geologia do Quaternário e mudanças ambientais (passado + presente $=$ futuro?). São Paulo, Paulo's Comunicação e Artes Gráficas, 366p.

Thomé, J.C.A.; C. Baptistotte; L.M.P. Moreira; J.T. Scalfoni; A.P. Almeida; D.B. Rieth \& P.C.R. Barata. 2007. Nesting biology and conservation of the Leatherback Sea Turtle (Dermochelys coriacea) in the State of Espírito Santo, Brazil, 1988-1989 to 2003-2004. Chelonian Conservation and Biology 6 (1): $15-27$.

Wyneken, J.; S.P. Epperly; L.B. Crowder; J. Vaughan \& K.B. Esper. 2007. Determining sex in posthatchling Loggerhead Sea Turtles using multiple gonadal and accessory duct characteristics. Herpetologica. 63 (1): 19-30.

ZAR, J.H. 2008. Biostatistical analysis. New Jersey, Prentice Hall, $5^{\text {th }}$ ed., 960 p.

Submitted: 16.IX.2010; Accepted: 03.I.2011.

Editorial responsibility: Cassiano Monteiro Neto 